\title{
Comparison of the Life Satisfaction Level of Recreational Choir Singers and Non-Choir Singers
}

\author{
Rekreasyonel Korolarda Korist Olanlarla Korist Olmayanların Yaşam \\ Doyumlarının Karşılaştırılması
}

Faik ARDAHAN*

\begin{abstract}
The main aim of this study is to compare the Life Satisfaction (LS) level of Recreational Choir Singers and Non-choir singers and define the effect of motivational factors to be a choir singer, the LS by using the linear regression model of LS and the benefits of participating in a choir as a singer. This research is descriptive research restricted to the choir singers in Antalya city centre. In this study, the questionnaire was handed to all choir singers $(n=653)$ in Antalya and collected within 15 minutes. The questionnaire was designed to address demographic variables, and The Satisfaction with Life Scale(SWLS) developed by Diener, Emmons, Larsen and Griffin (1985) adapted into Turkish by Köker (1991) and The Motivational Factors Scale of Being Choir Singer (MFSCS) developed by Ardahan (2016) was used. The LS level of non-choir singers was collected through an electronic questionnaire form from social media. As a result of this study it was found that participating in a choir as a choir singer has positive effect on LS. In other words when the LS level of recreational choir singers is compared with non-choir singers, the LS level of the choir singers is higher. In addition to this result, when the LS level of the choir singers is compared, there is no statistically meaningful difference due to marital status, gender, and being a salary earner, but there is a statistically meaningful difference by monthly income, the higher the income, the higher the LS level is. In addition to these, there is a statistically meaningful positive correlation between LS and age. The seven sub dimensions of MFSCS have a positive correlation with LS.
\end{abstract}

Anahtar sözcükler: Life Satisfaction, Choir, Choir Singer, Recreation

$\ddot{O}_{z:}$ Bu çalışmanın temel amacı rekreasyonel korolarda korist olanlarla korist olmayanların yaşam doyum (YD) düzeylerinin karşılaştırılması ve bireyleri korist olmaya motive eden motivasyonel faktörlerin korolara katılarak elde edilen faydalarla ve bu faktörlerin bireylerin YD'larına etkisinin doğrusal regresyon modeliyle sorgulanmasıdır. $\mathrm{Bu}$ çalışma tanımlayıcı bir çalışmadır ve Antalya şehir merkezindeki korolarla sınırlandırılmıştır. Çalışmada kullanılan anket formu Antalya'daki korolara katılan bireylere $(n=653)$ dağıtıldıktan $15 \mathrm{dk}$ sonra toplanmıştır. Bu çalışmada kullanılan anket formunda demografik değişkenlerin yanında Diener, Emmons, Larsen and Griffin (1985) tarafindan geliştirilen ve Köker (1991) yılında Türkçeye uyarlanan YD ölçeği ve Ardahan (2016) tarafından geliştirilen Bireyleri Korolarda Korist Olmaya Motive Eden Faktörler ölçeği (MFSCS) kullanılmıştır. Yaşamları boyunca hiçbir şekilde korist olmayanların verileri sosyal medya üzerinden toplanmıştır. Sonuç olarak rekreasyonel korolara korist olarak katılmak bireylerin YD'ları üzerinde pozitif etkiye sahiptir. Diğer bir deyişle, rekreasyonel korolarda korist olanlarla korist olmayanların yaşam doyum düzeyleri karşılaştırıldığında, korolara korist olarak katılanların YD'ları daha yüksektir. Bu sonuca ilave olarak, rekreasyonel korolara korist olarak katılanların YD'ları cinsiyet, medeni hal, kişisel gelir ve çalışma durumuna göre istatistiki olarak anlamlı bir farklılık göstermezken, kişisel gelire göre istatistiki olarak anlamlı farklılık yaratmakta, gelir arttıkça YD düzeyi de artmaktadır. Buna ilave olarak Yaş ve YD arasında ve MFSCS ölçeğinin yedi alt boyutu ile YD arasında istatistiki olarak anlamlı pozitif bir ilişki vardır.

Keywords: Yaşam Doyumu, Koro, Korist, Rekreasyon

* Doç. Dr. Akdeniz Üniversitesi, Spor Bilimleri Fakültesi, Rekreasyon Bölümü, Antalya. ardahan@akdeniz.edu.tr 


\section{Introduction}

Human relations with music usually start with their mothers' and/or other care givers' cradlesong/lullaby (Bailey \& Davidson, 2002) and they believe this is the one way to communicate with the baby (Papousek 1996). Many theoretical approaches suggest that music has an important role in influencing human daily life and emotional life as intrinsic and/or extrinsic motivators. Sometimes it can be a main reason for behavior and the tool having interaction with the world outside the self and plays a significant role in adaptation in the cognitive, emotional, social, and physical processes of behavior (Kaemmer, 1993). There are there types of singing; firstly; solitary occupation (a choir singer comprehending his/her experience completely alone singing by oneself-), secondly; shared occupation (a choir singer's experience runs in a parallel way instead of interactive - singing the national anthem together with others in the beginning of a sporting event) and thirdly; the most social of occupations called co-occupation (the need more than two persons having interaction between them). Singing in a choir as singer can be accepted as co-occupation (Jacob, Guptill \& Sumsion 2009).

In music literature, there are two kinds of participation, defined as active and passive. In much research, the researchers focused on the uses and the effects of listening to music which is passive participation and the complexity and diversity of listening experience. The active participation can be defined as making music (Bailey \& Davidson 2002). The Flow Theory developed by Csikszenrmihalyi (1997) has insights on the importance of the active participation on life satisfaction, mental absorption, whereas passive activities result in dissatisfaction and mental entropy. In addition to these, active participation and group singing usually create social interaction and an increase in happiness, self-esteem and decreasing in loneliness, opportunities for experiencing mental stimulation's positive effects.

There are many reasons for demanding participation in recreational activities for relaxing, improving oneself, having new social relations, achieving self-realization, spending time with friends/family, taking social responsibility, avoiding of boredom, escaping from responsibility, crowd, routine, family and someone else, belonging to a group, making new friends, improving and taking social status and power, being recognized, helping others, learning new skills, having physical, emotional and mental rehabilitation and fitness, being a fighter or to challenge or revolting, whether casual or serious, indoor or outdoor, with a group or alone, free of charge or not, official or not (Burnett 1994; McKenzie 2000; Cordes \& Ibrahim 2003; Ardahan 2011b). Listening to music or singing in a choir is casual or serious leisure.

Participating in a choir as a singer or as a listener to the concert, needs the motivational factor to begin, and or, to continue. To explain these motivational factors, Crandal (1980) and Levy (1979) say that the personality and the conditions and their interactions have effect on the beginning and continuity. In addition to these, the other motivational theories, a) Self Determination Theory developed by Deci and Ryan (1985) with intrinsic and extrinsic motivation, b) the Achievement Goal Theory developed by Pintrich (2000) with outcome oriented goals and task oriented goals, c) Needs Theory developed by Maslow (Ibrahim \& Cordes 2002), d) Activity Theory developed by Engeström, Miettinen and Punamaki (2003), and e) Lawler (1973) add an conclusion to these motivational theories, as the action is the result of physiological and psycho-social outcomes.

Tinto (1975) studied a theory called Tinto's Theory of Individual Departure. In this theory it was claimed that parents who were interested/involved in music, usually support their children's decision to study music, and they usually follow their steps (Sichivitsa, 2003). Ucan (1997)

claimed that music and participating in a choir has certain effects on human life, such as social 
benefits, economic benefits, individualistic benefits, cultural and educational functions and benefits. Beck et al. (2000) reported that group singing had positive emotional, physical, creative and emotional outcomes. Clift and Hancox (2001) found that singing in a choir as choir singer improves social, emotional, physical and spiritual health. Pitts (2004) concluded that singing provided achievements, opportunity to escape for a while everyday responsibilities, frustrations of realities, and challenge, the opportunity to make and developed new friendships who those have the same interest. In addition to these; Bailey \& Davidson $(2002 ; 2003 ; 2005)$ explored the matter of group singing providing positive life changes, and bringing the opportunity to obtain benefits associated with the group process, therapeutic benefits, benefits assignable to choir/audience provision, and benefits obtained from mental stimulation.

Many researchers describe how important and how significance passive participation such as listening to music and/or active participation such as singing and health and/or healing (Clift $\&$ Hancox 2001). Participating in musical activity (passive in an audience or active as a singer) with amateur expectations is a recreational behavior which has many reasons behind it. These can be defined as the benefits of singing in a choir as a singer; and listed as: feeling more important, feeling relaxed and refreshed, taking responsibility for self and others, spending time with family members and/or friends, finding mental and emotional fitness, improve personal borders, belonging to a group, making friends and new connection, feeling happier, finding selfconfidence, socialization, feeling ready for new challenges, being generous to diversity and a fault, improve and developed new skills and ability, defeat stage fright, escape from sameness, distress and stress, having the therapeutic touch of music, challenge any fear, having motivation for other activities, get rid of the being alone feeling, having the opportunity to develop life skills and team work skills, having the opportunity to express parts of his/her personality and exercising the brain, (Bruce et al. 1976; Weissinger \& Bandalos 1995; McKenzie 2000; Cordes \& Ibrahim 2003; Jacob et al. 2009; ). All these benefits can be accepted as determiners of the happiness and/or life satisfaction.

Satisfaction has many classifications like: life satisfaction (LS), social satisfaction, emotional satisfaction, marital and role satisfaction, leisure satisfaction, economic and professional satisfaction. All these effect and effected from ones' whole physical, emotional, mental and professional life and all kind relationships and interactions (Ardahan 2014). LS can be defined as the global perception and/or decision of an individual about his/her life or emotional attitude derived from his/her life and a general attitude towards the life and one's LS level can be measured through the realization of the level of expectations (Diener 1984; Diener et al. 1985; Pavot \& Diener 1993; Sung-Mook \& Giannakopoulos 1994; Rodriguez, Latkova \& Sun 2008; Ardahan 2011a; 2011b; 2012).

LS can be affected by many factors such as confidence in physical health, having meaningful and satisfied interaction and/or relationships with others including family members, friends, colleagues, relatives and others, quality of life, economic security and sufficiency, satisfactory income, reaching goals, having a meaningful marriage or relationship, helping others, physical, emotional and mental wellness, having close friends, having a positive personality or being an optimist, participating or having the opportunity to participate in recreational activities, pleasure retrieved from daily life, finding life's worth living, having a child, having a house/flat/car, having hobbies, and many other things (Bruce et al. 1976; SungMook \& Giannakopoulos 1994; Palmer et al. 2002; Schmitter et al. 2003; Ngai 2005; Augusto et al. 2006; Ardahan 2011a; 2011b) 
When individuals find pleasure and/or get positive satisfaction from leisure participation it has a positive impact on LS (Ngai 2005).

\section{Method}

The main aim of this study was to compare the Life Satisfaction (LS) level of Recreational Choir Singers and Non-choir singers and to define the effect of motivational factors to be a choir singer on LS by using the linear regression model of LS and the benefits of participating in a choir as choir singer. The scope of this study is restricted to the recreational choir singers in city center of Antalya.

Sampling group of this study consisted of 653 choir singers in 37 amateur choirs. The exact number of the choirs in the center of Antalya was 43 and six choirs were excluded from this study, two because they were professional and four because they did not want to join the survey.

The designed questionnaire addresses demographic variables, and The Satisfaction with Life Scale-(SWLS) developed by Diener et al. (1985) adapted into Turkish by Köker (1991) and The Motivational Factors Scale of Being Choir Singer (MFSCS) developed by Ardahan (2016) was used. A five-point Likert scale was used for scales and benefit items and the range covers (1: definitely disagree, 5: definitely agree). In this study, the questionnaire was handed to all choir singers and collected back in 15 minutes. The LS level of non-choir singers $(n=296)$ was collected through an electronic questionnaire form in the social media.

In the processing of assessing the data, descriptive statistic methods, linear regression model has been used, the results have been assessed according to significant level 0.01, 0.05 and 0.10.

Linear regression model of LS is below;

LS $=\alpha_{0}+\alpha_{1}$ Relaxing Mentally $+\alpha_{2}$ Renovate/Develop $+\alpha_{3}$ To be away / Escape

$+\alpha_{4}$ Socialization $+\alpha_{5}$ Recognition and Social status $+\alpha_{6}$ Liking Music

$+\alpha_{7}$ Exemplifying $+\alpha_{8}$ Age $+\alpha_{9}$ Female $+\alpha_{10}$ Single $+\alpha_{11}$ High School

$+\alpha_{12}$ University $+\alpha_{13}$ Post graduate and upper $+\alpha_{14}$ Employed $+\alpha_{15}$ Unemployed

$+\alpha_{16} 351-700 \$$ monthly income $+\alpha_{17} 701-1050 \$$ monthly income

$+\alpha_{18} 1051-1400 \$$ monthly income $+\alpha_{19} 1401 \$$ and above monthly income $+\mathrm{u}$

In this equation, $\alpha_{i}$ is constant, $\mathrm{u}_{\mathrm{i}}$ is disturbance terms, LS which is dependent variable and independent variables are listed in Table-1. Ordinary least square (OLS) estimators were used to estimate the coefficients of equation. Heteroscedasticity was checked and the BreuschPagan/Cook-Weisberg test was performed and $\mathrm{Chi}^{2}=18.48, \mathrm{p}>\mathrm{Chi}^{2}=0.000$ were found which is enough to reject the null hypothesis of constant variance for the model. So, robust standard errors of the coefficients were computed because of heteroscedasticity in the model. Then, possible multicollinearity problem and calculated variance inflation factors (VIF) for each independent variable in the model were checked and it was found that the maximum VIF value is 4.26 which is within limits (Gujarati 2003). Finally, because of the large sample size, the disturbances are assumed as normally distributed. If the sample size is large, the Central Limit Theorem accepts that normal distribution can be performed, even if disturbances are not normal (Baltagi 2008). 


\section{Findings}

The descriptive statistics of the components are given in Table-1. As seen in the table; the first important three factors of participating a choir as are singer are "Liking Music", "Relaxing Mentally" and "Renovate/Develop". Their life satisfaction is not so high and the average age is 53.16 years old. The majority of the choir singers were female, married, well educated, retired and have $1050 \$$ and lower personal monthly income. The LS level of the choir participants is higher than the non-choir participants and there are statistically meaningful differences $(t=5.154$ $\mathrm{p}=0.000$ ) in favour of the choir participants.

Table 1. Descriptive Statistics of Components

\begin{tabular}{|c|c|c|c|c|c|}
\hline Variables & $\begin{array}{c}\text { Mea } \\
\mathbf{n}\end{array}$ & S.D. & Variables & $\mathbf{n}$ & $\%$ \\
\hline F1- Like Music & 4.35 & 0.74 & Married & 410 & 62.8 \\
\hline F2- Relaxing Mentally & 4.10 & 0.81 & Single & 243 & 37.2 \\
\hline F3- Renovate/Develop & 3.99 & 0.86 & Primary School & 53 & 8.1 \\
\hline F4- Socialization & 3.39 & 0.94 & High School & 247 & 37.8 \\
\hline F5- Exemplifying & 3.29 & 1.24 & University & 284 & 43.5 \\
\hline F6- To be away/Escape & 2.75 & 1.13 & Post graduate and above & 69 & 10.6 \\
\hline F7- Recognition and Social status & 2.73 & 1.19 & Retired & 372 & 57.0 \\
\hline Life Satisfaction of Choir Singer & 3.44 & 0.83 & Employed & 169 & 25.9 \\
\hline Life Satisfaction of Non Choir Singer & 3.13 & 0.88 & Unemployed & 112 & 17.2 \\
\hline Age min-max (13-87) & 53.16 & 13.23 & $350 \$$ and lower monthly income & 89 & 13.6 \\
\hline Variables & $\mathbf{n}$ & $\%$ & $351-700 \$$ monthly income & 274 & 42.0 \\
\hline Male & 260 & 39.8 & $701-1050 \$$ monthly income & 187 & 28.6 \\
\hline Female & 393 & 60.2 & 1051-1400\$ monthly income & 62 & 9.5 \\
\hline \multirow{2}{*}{\multicolumn{3}{|c|}{$\begin{array}{l}\text { PS: Currency rate is } 1 \$=2.85 \mathrm{TL} \text { and } \\
\text { minimum wage is } 456 \$ \text { in Turkey in June } 2016\end{array}$}} & $\begin{array}{l}1401 \$ \text { and above monthly } \\
\text { income }\end{array}$ & 41 & 6.3 \\
\hline & & & Total & 653 & $\mathbf{1 0 0 . 0}$ \\
\hline
\end{tabular}

The result of the regression model is given in Table-1. As seen in this Table, the model is significant $(\mathrm{F}=14.01, \mathrm{p}=0.000$ for the model). The variables "Relaxing Mentally" (Coef. $=0.1230$, $\mathrm{p}=0.046)$, "Socialization" (Coef. $=0.1910, \mathrm{p}=0.000)$, "Recognition and Social status" (Coef.= 0.1111, p=0.001), "Liking Music" (Coef. $=0.1030, \mathrm{p}=0.044)$, "Exemplifying" (Coef. $=0.0973$, $\mathrm{p}=0.003)$, "Age" (Coef. $=0.0055, \mathrm{p}=0.086)$ have positive and significant effects and the variable "To be away / Escape" (Coef.= $-0.0554, \mathrm{p}=0.076$ ) has negative and significant effects on LS. This means that one unit increase/decrease in these variables; LS will increase/decrease as a coefficient value. In addition to these, when compared with being male; being female (Coef. $=0.1400$, $\mathrm{p}=0.030$ ), when compared with having $350 \$$ and below monthly income; having monthly income of 1051-1400\$ (Coef. $=0.5913, \mathrm{p}=0.000)$ and $1401 \$$ and above (Coef. $=0.6614, \mathrm{p}=0.000)$ has a positive and significant effect on LS. On the other hand, when compared, being a graduate from Secondary School; being a graduate from High School (Coef. $=-0.2009, p=0.046)$ and from University (Coef. $=-0.1822, p=0.088$ ) has a negative and significant effect on LS. This means that the higher the income, the higher the LS and the higher the graduation, the higher the LS. Age has positive and significant effects the on LS level. When individuals age, LS level increases. Being retired or jobless including being unemployed, a housewife or student may be a reason or give opportunity to participate in a choir as a choir singer, but it has no effect on the individuals LS. Even if, the coefficient value of the sub dimension "To be away / Escape" has a negative sign, this has a positive meaning, because of the Likert value ranges 1: definitely disagree to 5: definitely agree. This means that the average value of the sub dimension "To be away / Escape" approaches 1 , the individuals do prefer participating in choir, not for escaping from something, and this has a positive effect on LS. 
Table 2. Life Satisfaction Regression Model

\begin{tabular}{|c|c|c|c|}
\hline $\begin{array}{l}\mathrm{N} \\
\mathrm{F}(19.633) \\
\text { Prob. } \\
\mathrm{R}^{2}\end{array}$ & $\begin{array}{l}653 \\
14.01 \\
0.000 \\
0.2852 \\
\end{array}$ & & \\
\hline Variables & Coef. & Robust St. Err. & $\mathbf{p}$ \\
\hline Cons. & $1.0083^{* * *}$ & 0.3028 & 0.001 \\
\hline Relaxing Mentally & $0.1230 * *$ & 0.0616 & 0.046 \\
\hline Renovate/Develop & -0.0162 & 0.0573 & 0.777 \\
\hline To be away/Escape & $-0.0554^{*}$ & 0.0311 & 0.076 \\
\hline Socialization & $0.1910 * * *$ & 0.0474 & 0.000 \\
\hline Recognition and Social status & $0.1111 * * *$ & 0.0340 & 0.001 \\
\hline Liking Music & $0.1030 * *$ & 0.0511 & 0.044 \\
\hline Exemplifying & $0.0973 * * *$ & 0.0323 & 0.003 \\
\hline Age & $0.0055^{*}$ & 0.0032 & 0.086 \\
\hline Female & $0.1400 * *$ & 0.0644 & 0.030 \\
\hline Single & 0.0641 & 0.0657 & 0.330 \\
\hline High School & $-0.2009 * *$ & 0.1004 & 0.046 \\
\hline University & $-0.1822 *$ & 0.1066 & 0.088 \\
\hline Post graduate and upper & -0.1484 & 0.1428 & 0.299 \\
\hline Employed & -0.0581 & 0.0804 & 0.471 \\
\hline Unemployed & -0.0047 & 0.1079 & 0.965 \\
\hline $351-700 \$$ monthly income & 0.1573 & 0.1133 & 0.166 \\
\hline 701-1050\$ monthly income & 0.1588 & 0.1172 & 0.176 \\
\hline 1051-1400\$ monthly income & $0.5913 * * *$ & 0.1402 & 0.000 \\
\hline $1401 \$$ and above monthly income & $0.6614 * * *$ & 0.1567 & 0.000 \\
\hline
\end{tabular}

* significant at .10 level, $* *$ significant at .05 level, $* * *$ significant at .01 level

The benefits of individuals who participated in a choir as a choir singer are given in Table-3. As seen in the table, the choir singer: "feels happier", "satisfied", "learned new things", "makes new friends", "feels relaxed and refreshed" and "spend their time more qualified and productive". All benefits have strong, positive and significant correlations with LS and majority of motivational factors.

Table 3. The Benefits of Being a Choir Singer and the Pearson Correlations with LS and The Sub Dimension of Motivational Factors Scale of Being a Choir Singer

\begin{tabular}{|c|c|c|c|c|c|c|c|c|c|c|}
\hline Benefits and Factors & Mean & SD & F1 & F2 & F3 & F4 & F5 & F6 & F7 & $\mathbf{L S}$ \\
\hline Feel happier & 4.24 & 0.98 & $0.396^{*}$ & $0.483 *$ & $0.388^{*}$ & $0.325 *$ & $0.238 *$ & 0.034 & 0.067 & $0.415^{*}$ \\
\hline Learned new things & 4.21 & 1.01 & 0.33 & 0.42 & $0.409^{*}$ & 0 . & $0.246^{*}$ & $0.115^{*}$ & $0.177 *$ & $0.396^{*}$ \\
\hline Meet new friends & 4.18 & 0.96 & 0.30 & & 0.44 & 0 . & 0.329 & 0.15 & $0.324 *$ & $0.395 *$ \\
\hline Feel relaxed and refreshed & 4.10 & 1.01 & $0.421 *$ & $0.494 *$ & $0.489 *$ & & $0.261 *$ & 0.033 & $0.129 *$ & $0.451 *$ \\
\hline $\begin{array}{l}\text { Spent the time more qualified and } \\
\text { productive }\end{array}$ & 4.05 & 1.01 & 0.36 & 0.50 & $0.493 *$ & 0.41 & $0.324 *$ & $0.106^{*}$ & 0.1 & $0.379 *$ \\
\hline Get self-satisfaction & 3.95 & 1.08 & 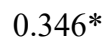 & 0.1 & & & 0.207 & 0.0 & 0.13 & $0.387 *$ \\
\hline $\begin{array}{l}\text { Developed myself on rhythm, } \\
\text { solmization, musical note }\end{array}$ & 3.94 & 1.26 & 0.2 & 0.3 & 0.45 & 0.4 & $0.368 *$ & 0.18 & & $0.277 *$ \\
\hline ed self-confidence & 3.90 & .17 & 0.28 & & & & 0 & & & $0.316^{*}$ \\
\hline Feel belonging to a group & 3.85 & 1.13 & 0.26 & 0.3 & 0.4 & 0.4 & 0.28 & 0.1 & 0.2 & $0.321 *$ \\
\hline $\begin{array}{l}\text { After practice, worked more } \\
\text { productively }\end{array}$ & 3.82 & 1.11 & 0.3 & 0.44 & 0.428 & 0.39 & $0.300^{*}$ & 0.069 & 0.16 & $0.405^{*}$ \\
\hline $\begin{array}{l}\text { Escaped from sameness, distress } \\
\text { and stress }\end{array}$ & 3.74 & 1.27 & $0.156^{*}$ & $0.236^{*}$ & $0.305^{*}$ & $0.424 *($ & 0.29 & 0.26 & 0.42 & $0.314^{*}$ \\
\hline My imagination on music increased & 3.70 & 1.18 & 0.2 & 0.3 & 0.3 & 0.4 & $.285^{*}$ & 0.21 & $0.317 *$ & $0.386^{*}$ \\
\hline Get rid of the being alone feeling & 3.40 & 1.36 & $0.191 *$ & $0.219 *$ & $0.224 *$ & $0.162 *($ & $0.191 *$ & $0.114 *$ & $0.223 *$ & $0.298 *$ \\
\hline
\end{tabular}




\section{Conclusions}

The linear regression model used in this study takes The Motivational Factors Scale of Being Choir Singer (MFSCS) and some demographics variables as independent variables to examine the level and direction of its effect on LS.

Even if the coefficient value of the sub dimension "To be away / Escape" has a negative sign, this has positive meaning, because of the Likert value range 1: definitely disagree to 5 : definitely agree. This means that the average value of the sub dimension "To be away / Escape" approaches 1, the individuals do not prefer participating in choir not for escaping from something, and this has positive effect on the LS. The seven sub dimensions of MFSCS have a positive correlation with LS. It can be concluded that, if positive experience achieved, participating in leisure activities, whether casual or serious, indoors or outdoors, in a group or alone, free of charge or not, official or not has a positive effect on leisure satisfaction, social satisfaction, emotional satisfaction and LS (Ardahan, 2011a, 2011b, 2012, 2014; Ibrahim and Cordes, 2002; Rodriguez at al. 2008). The result of the current study verifies that when they are compared, the LS level of the choir singers and non-choir singers, the choir singers have a higher LS and this overlaps with the leisure literature concerning LS.

There is positive correlation between the reason and the benefits or outcomes as was expected. The reason is the main determiner/motivator of the action and if the reason is realized satisfaction was found. The benefit and outcomes which have a positive effect on the LS of those participating as a choir singer choir overlap with the conclusion and the results of Bailey and Davidson (2002; 2003; 2005), Beck et al. (2000), Clift and Hancox (2001), Cordes and Ibrahim (2003), Jacob et al. (2009), Pitts (2004), Ucan (1997), Weissinger and Bandalos (1995).

In many studies, the positive contribution of a good marriage to LS was emphasized (Hicks \& Platt 1970; Laws 1971). In the current study, the number of maried participants (\%62.80) are higher then single (\%38.20), while the outdoor sports participants were single. In addition, it was found that, being female has positive advantages in participating in a choir, in contrast to participating in outdoor activities (Ardahan, 2011a, 2011b). The majority of choir participants are female $(\% 60.20)$ and married but there is no meaningful difference in the LS level by gender and marital status. It can be concluded that choirs are not under "Male Hegemony".

The higher income gives individuals greater opportunity to participate in leisure activities alone or in a group than individuals with lower income (Ardahan 2011b; İbrahim \& Cordes 2002), and higher income usually gives a higher LS (Diener 1984; Diener et al. 1985). The result of the current study verifies this conclusion.

White (1975) concluded and Ardahan (2011b) also found that there is a positive correlation between age, education level and LS. When the age of individuals increase, their education level increases and depending upon this, their LS will increase. But in this study, it was found that there is a negative effect of the education level on LS. The reasons of this could be, a) the majority of participant were retired, b) education level of them were high school and below and b) their retirement pensions are not high.

It is expected that as individuals age, many structural problems (having an occupation, getting married, raising a child, improving a professional and social career, etc.) and basic needs (buying a car, having a house/flat, a holiday etc.) of individuals were solved over the years depending upon his/her age (Diener 1984; Diener et al. 1985; Ardahan 2011b). And this has positive effect on the individuals LS level. The results of the current study support this conclusion. 
From much research, it was concluded that being employed has positive effect on LS (Diener 1984; Diener et al. 1985), but in this study, it was found that there is no difference between the unemployed, employed or retired participants' LS level. The reason for this can be the therapeutic touch of the music.

\section{Result}

As a result of this study it was found that participating in a choir as a choir singer has positive effect on LS. In other words when the LS level of recreational choir singers is compared with non-choir singers, the LS level of the choir singers is higher. In addition to this result, when the LS level of the choir singers is compared, there is no statistically meaningful difference due to marital status, gender, and being a salary earner, but there is a statistically meaningful difference by monthly income, the higher the income, the higher the LS level is. In addition to these, there is a statistically meaningful positive correlation between LS and age. The seven sub dimensions of MFSCS have a positive correlation with LS. 


\section{REFERENCES}

Ardahan F. (2011a). "Examining Relation Between Emotional Intelligence and Life Satisfaction on the Example of Outdoor Sports Participants". I I International Sport Economy and Management congress, 12-15th Oct 2011, Izmir, Turkey.

Ardahan F. (2011b). "The Profile of the Turkish Mountaineers and Rock Climbers: The Reasons and the Carried Benefits for Attending Outdoor Sports and Life Satisfaction Level". $8^{\text {th }}$ International Conference Sport and Quality of Life/2011, 10-11 Nov 2011, Congress Centre-Brno/Czech Republic.

Ardahan F. (2012). "Examining the Relation Between Social Capital, Life Satisfaction and Academic Achievement: School of Physical Education and Sport Case". Poster Presentation. $12^{\text {th }}$ International Sport Sciences Congress, 12-14 $4^{\text {th }}$ December, Denizli-Turkey.

Ardahan F. (2014). "The Effect of Participating in Official Recreational Activities on Organizational Citizenship, Organizational and Professional Commitment, Life Satisfaction and Achievement Perception". The Online Journal of Recreation and Spor 3/3 (2014) 7-17.

Ardahan F. (2016). "The Motivational Factors Scale of Being Choir Singer (MFSCS)". $4^{\text {th }}$ International Academic Conference on Social Sciences (IACSS 2016), 28-29 July 2016, Barcelona, Spain.

Augusto J. M., Lo'pez-Zafra L. E., Martínez de Antoñana R. \& Pulido M. (2006). "Perceived Emotional Intelligence and Life Satisfaction Among University Teachers". Psicothema 18 (2006) 152-157.

Bailey B. A. \& Davidson J. W. (2002). "Adaptive Characteristics of Group Singing: Perceptions from Members of a Choir Forhomeless Men". Musicae Scientiae 6/2 (2002) 221-256.

Bailey B. A. \& Davidson J. W. (2003). "Amateur Group Singing as a Therapeutic Instrument". Nordic Journal of Music Therapy 12/1 (2003) 18-32.

Bailey B. A. \& Davidson J. W. (2005). "Effects of Group Singing and Performance for Marginalized and Middle-Class Singers". Psychology of Music 33/3 (2005) 269-303.

Baltagi B. H. (2008). Econometrics. Berlin 2008.

Beck R., Cesario T., Yousefi S. \& Enamoto H. (2000). "Choral Singing, Performance Perception and Immune System Changes in Salivary Immunoglobulin and Cortisol". Music Perception 18/1 (2000) 87-106.

Bruce A. C., Stan L. A. \& Phillip R. K. (1976). "Marital and Family Role Satisfaction". Journal of Marriage and Family 38/3 (1976) 431-440.

Burnett D. (1994). "Exercising Better Management Skills". Personnel Management 26/1 (1994) 42-46.

Clift S. \& Hancox G. (2001). "The Perceived Benefits of Singing: Findings from Preliminary Surveys of a University College Choral Society". Journal of the Royal Society for the Promotion of Health 121/4 (2001) 248-256.

Cordes K. A. \& Ibrahim H. M. (2003). Applications in Recreation and Leisure for Today and Future. New York $2003^{3}$.

Crandall R. (1980). "Motivation for Leisure". Journal of Leisure Research 12/1 (1980) 45-54.

Csikszenrmihalyi M. (1997). Finding Flow: The Psychology of Engagement with Everyday Life. New York 1997.

Deci E. L. \& Ryan R. M. (1985). "The General Causality Orientations Scale: Self Determination in Personality". Journal of Research in Personality 19 (1985) 109-134.

Diener E. (1984). "Subjective Well-being". Psychological Bulletin 95/3 (1984) 542-575.

Diener E., Emmons R. A., Larsen R. J. \& Griffin S. (1985). "The Satisfaction with Life Scale". Journal of Personality Assessment 49 (1985) 71-75.

Engeström Y., Miettinen R. \& Punamaki R. L. (2003). Perspective On Activity Theory. New York $2003^{2}$. Gujarati D. N. (2003). Basic Econometrics. New York $2003^{4}$.

Hicks M. W., Platt M. (1970). "Marital Happiness and Stability: A Review of the Research in the Sixties". Journal of Marriage and the Family 32 (1970) 553-574.

İbrahim H. M. \& Cordes K. A. (2002). Outdoor Recreation, Enrichment for a Lifetime. Sagamore 2002.

Jacob C., Guptill C. \& Sumsion T. (2009). "Motivation for Continuing Involvement in a Leisure-based 
Choir: The Lived Experiences of university Choir Members". Journal of Occupational Science 16/3 (2009) 187-193.

Kaemmer E. (1993). Musicin Human Lift: Anthropological Perspectives on Music. Austin 1993.

Köker S. (1991). Normal ve Sorunlu Ergenlerin Yaşam Doyumu Düzeylerinin Karşılaştırılması. Yayımlanmamış Yüksek Lisans Tezi. Ankara Üniversitesi, Ankara 1991.

Lawler E. E. (1973). Motivations in Work Organizations. Monterey 1973.

Laws J. L. (1971). "A Feminist Review of Marital Adjustment Literature: The Rape of Locke". Journal of Marriage and the Family 33 (1971) 483-516.

Levy J. (1979). "Motivation for Leisure: An Intereactionist Approach". Eds. H. Ibrahim \& R. Crandall, Leisure: A Psychological Approach (1979). Los Alamitos.

McKenzie M. D. (2000). "How are Adventure Education Program Outcomes Achieved?: A Review of the Literature". Australian Journal of Outdoor Education 5/1 (2000) 19-28.

Ngai V. T. (2005). "Leisure Satisfaction and Quality of Life in Macao, China". Leisure Studies 24/2 (2005) 195-207.

Palmer B., Donaldson C. \& Stough C. (2002). "Emotional Intelligence and Life Satisfaction”. Personality and Individual Differences 33 (2002) 1091-1100.

Papousek M. (1996). "Intuitive Parenting: A Hidden Source of Musical Stimulation in Infancy". Ed. I. Deliege, Musical Beginnings: Origins and Development of Musical Compaence (1996) 88-112. New York.

Pavot W. \& Diener E. (1993). "Review of the Satisfaction with Life Scale". Psychological Assessment 5/2 (1993) 164-172.

Pintrich P. R. (2000). “An Achievement Goal Theory Perspective on Issues in Motivation Terminology, Theory and Research". Contemporary Educational Psychology 25 (2000) 92-104.

Pitts S. E. (2004). “'Everybody Wants to Be Pavarotti': The Experience of Music for Performers and Audience at a Gilbert and Sullivan Festival". Journal of the Royal Musical Association 129 (2004) 149167.

Rodriguez A., Latkova P. \& Sun Y. Y. (2008). "The Relationship Between Leisure and Life Satisfaction: Application of Activity and Need Theory". Social Indicators Research 86 (2008) 163-175.

Schmitter C., Zisselman M. \& Woldow A. (2003). "Life Satisfaction in Centenarians Residing in Longterm Care". Annals of Long Term Care 7/2 (2003) 437-442.

Sichivitsa V. O. (2003). "College Choir Members' Motivation to Persist in Music: Application of the Tinto Model". JRME 51/4 (2003) 330-341

Sung-Mook H. \& Giannakopoulos E. (1994). "The Relationship of Satisfaction with Life to Personality Characteristics". Journal of Psychology Interdisciplinary and Applied 128/5 (1994) 547.

Tinto V. (1975). "Dropout from Higher Education: A Theoretical Synthesis of Recent Research". Review of Educational Research 45 (1975) 89-125.

Ucan A. (1997). Müzik Eğitiminde Temel Kavramlar-İlkeler-Yaklaşımlar. Ankara 1997.

Weissinger E. \& Bandalos D. L. (1995). "Development, Reliability and Validity of a Scale to Measure Intrinsic Motivation in Leisure". Journal of Leisure 27/4 (1995) 379-400.

White T. H. (1975). "Relative Importance of Education and Income as Predictors in Outdoor Recreation Participation". Journal of Leisure Research 7/3 (1975) 191-199. 